\title{
Non Hormonal Induction of Oestrus in Nellore Ewes
}

\author{
Bala Krishna Rao Dabbir \\ Consultant, Sreepathi Veterinary Services, Kadapa \\ Corresponding author: bdabbir@gmail.com
}

\begin{abstract}
A non hormonal induction of synchronization of estrus in ewes of Nellore breed, in two seasons June-July and September - October, covering 39980 and 42370 ewes respectively, spread over 2015 to 2019, with micro minerals (Bioplex High Seven), after onset of monsoon and deworming the sheep, appropriate to the season and type of prevailing parasitic infection, were studied. All the supplemented ewes came to estrus within a week, and were bred with stud rams. After the completion of gestation period all the ewes were lambed within a week uniformly. This may be due to elimination of stress due to environment, nutrition, parasites, replenishment of minerals and stimulation of folliculogenesis with Bioplex. The current extension method induction of estrus is safe, economical, easy to adopt and eco-friendly.
\end{abstract}

Keywords: Non hormonal induction of estrus-Nellore ewes- Bioplex High Seven

Sheep is a seasonal breeder and shows their cyclicity, at three mating seasons viz. March to April or summer, June to July or autumn, September to October or post monsoon. Fertility is found to be high during autumn season in the plains whereas in the hilly region, it is summer season (Verma, 1999). After every 16 days on an average (Actual range 14-20 days) the ewe shows heat. The average length of heat period is 30 hours. Conception is best when breeding occurs late in heat period.

Synchronization of heat is the practice of bringing all the ewes of the flock together to heat within 2-3 days. Estrus synchronization is a valuable management tool for increasing pregnancy rate of ewes. Successful estrus synchronization programs have a key role on lambing rate efficiency and profitability of sheep holders under semi -intensive production systems (Knights et al. 2001). Ovarian response of sheep to estrus synchronization varies according to the type of intravaginal device, kind of progestagen, nutritional status, stress, environmental aspects, male effect (Kleemann and Walker, 2005) and breed (Boscos et al. 2002).

Practical advantages of this method are as follows (Khanvilkar et al. 2009).

Shepherd may plan the lambing time in such a way, when the climate is most suitable for raising the healthy lambs with least effort.

1. It saves labour charges as servicing and lambing takes place within the same short period.

2. Breeding by natural process or by A.I. becomes easier and economical.

3. Flock management is effective as all ewes are in the same stage of pregnancy.

How to cite this article: Dabbir, B.K.R. (2020). Non hormonal induction of oestrus in Nellore ewes. Theriogenology Insight, 10(1): 17-22.

Source of Support: None; Conflict of Interest: None 
4. Shepherd may plan breeding as per future market demands.

The major practice in vogue for synchronization of oestrus, is either using controlled intra-vaginal drug releasing devices (CIDR) or progesterone sponge alone or accompanied by gonadotropin (Rhodes and Nathaniels, 1998). Equine chorionic gonadotropin with a long half-life and no need for several injections is the mainly used gonadotropin for superovulation (Leyva et al. 1998; Ali, 2007; Wheaton et al. 1993). The use of exogenous hormones generally resulted in a high incidence of both behavioural oestrus and ovulation, but the conception rates for the induced oestrus during mid-anoestrus ranged from 21\% (Gordon, 1963) to 50\% (Brunner et al. 1964).

Another novel approach using non-hormonal agents i.e., kisspeptin peptide and sulpiride, a dopamine antagonist, has been successfully used for induction of oestrus in sheep at ICARCSWRI. Ovine kisspeptin was synthesized and administered@20 ug/ewe (single bolus Intravenous) which resulted in exhibition of oestrus and an 8-10 times increase in LH levels (Naqvi et al. 2017). Induction of estrus with proteins is in the experimental stage and may be expensive.

Good old practices namely ram effect and photo-period is promising in inducing the oestrus in non-breeding season. Ram effect induces secretion of $\mathrm{LH}$ and estrogen, which result in ovulation within 1 to 3 days (in some ewes, response may be slower, 4 to 7 days), but without the expression of oestrus. If the CL has a normal life span (12 to 14 days) oestrus and ovulation occur around 16 to 17 days after introduction of rams. Because such effects have been most obvious when the ewes were in states of physiological transition: either from nonbreeding to breeding season or were coming into estrus for the first time (Dyrmundsson \& Lees, 1972), it was hypothesized that once cyclic reproductive activity had been established, the occurrence and pattern of oestrus was no longer influenced by ram stimulation (Dyrmundsson \& Lees, 1972).

Free range system of sheep rearing often encounters various types of stress like:

1. Environmental stress including Temperature, Cold, Heat, Wind, Humidity,

2. Manage mental stress, Herd density, Social status, Transportation, alteration of routine, Psychological distress, Physical traumatic,

3. Parasitic, and

4. Nutritional consisting Poor or deficient forage.

1. The impact of stress on reproductive endocrinology

For efficient reproduction, follicles should grow at an appropriate rate in the ovaries, ovulation must occur and hormones need to be produced, not only to control pheromone release (to attract the ram at a time synchronous with ovum release into the female reproductive tract), but also to prepare the uterus to supporting the conceptus. This disruption in adult animals is usually temporary, so that, when prevailing conditions improve, normal fertility would resume.

\section{The impact of stress on oestrus behaviour}

Oestrus is delayed when ewes are below or above critical temperatures (thermal stress) (Doney et al. 1973), or when they are transported (Enhert and Moberg, 1991).

\section{The impact of Nutritional Stress}

Nutrition plays a key role in regulating the reproductive performance in farm animals (Maurya et al. 2010). This nutrition deficiency along with heat stress imposes severe effects on livestock production and reproduction. Zarazaga et al. (2004) reported that nutrition is an important factor affecting reproductive 
function and the onset of postpartum ovarian cyclicity in farm animals.

The phenomenon of feed 'flushing' has been incorporated into sheep management for many years to hasten seasonal breeding periods (Clark, 1934). There are several regimens for increasing ewe fertility by increasing energy availability as day-length decreases (with or without pre exposure to 'teaser' rams (WalkdenBrown et al. 1999).

There has been special interest in effects of dietary trace element deficiencies on physiological function and particularly on reproduction. Severe dietary deficiencies of copper, selenium (and zinc are commonly seen in ruminants (Monem and El-Shahat, 2011). Underwood (1981) stated that minerals have the functions of the body's metabolic processes, among the productive, and reproductive processes (Chan et al. 1998), are: structure, physiological, catalysts and regulator.

The dietary and tissue balance of antioxidant nutrients is important in protecting tissues against free radical damage Free radicals and reactive oxygen species play a number of significant and diverse roles in reproductive biology (Agarwal et al. 2006). Deficiency of free radicals may also arise due to different kinds of stress (McDowell et al. 2007).

Minerals such as Phosphorus, Calcium, Magnesium, Iodine, Manganese, Copper, Selenium, and Zinc are all involved in governing successful reproductive processes (Wilde, 2006).
Adequate micro minerals supplementation is required as most of the roughages, greens, concentrates and even most of commercial feeds available to Indian market are deficient in trace mineral elements. Superoxide radicals are reduced to hydrogen peroxide by superoxide dismutases in the presence of Copper and Zinc cofactors. Hydrogen peroxide is then reduced to water by the Se-glutathione peroxidase couple (Chan et al. 1998). Efficient removal of these superoxide free radicals maintains the integrity of membranes

In India, more than $80 \%$ of sheep are being reared under the Free Range System of Sheep Rearing. Nellore sheep is the tallest mutton breed of sheep in India which is widely distributed in Nellore district and neighboring areas of Prakasam and Kadapa districts of Andhra Pradesh. Three Strains are distinguished primarily on the basis of their coat colour. Nellore Jodipi is the most predominant population with white colour on the dorsal surface of the body with black colour under the belly. Nellore Palla is completely white in colour. Nellore Brown is completely brown in colour with little hair except at brisket, withers and breech regions on the body. The sheep numbering 82,350 brought to Sreepathi veterinary services, Kadapa during 2015 to 2019 were subjected to estrus synchronization with organic micro-minerals (Table 1).

\section{MATERIALS AND METHODS}

The shepherds dewormed 82350 ewes with either Anorox (A brand product of curevet

Table 1: Number of ewes selected for the study

\begin{tabular}{cccccc}
\hline \multirow{2}{*}{ SI. No. } & \multirow{2}{*}{ Year } & \multicolumn{2}{c}{ Number of ewes supplemented } & $\begin{array}{c}\text { Number of days the ewes } \\
\text { exhibited and bred (93\%) }\end{array}$ & $\begin{array}{c}\text { Lambing pattern } \\
\mathbf{( 9 0} \text { to 93\%) }\end{array}$ \\
\cline { 3 - 5 } & & June- July & September-October & $3-7$ & $140-147$ \\
2 & 2015 & 6025 & 7045 & $3-7$ & $140-147$ \\
3 & 2016 & 8010 & 8024 & $3-7$ & $140-147$ \\
4 & 2018 & 8241 & 9424 & $3-7$ & $140-147$ \\
5 & 2019 & 10248 & 8012 & $3-7$ & $140-147$ \\
\hline
\end{tabular}

Online ISSN: 2277-3371 
formulation, Hyderabad containing Rafoxanide with levamisole) or Neozide Plus (A brand product of Intas Ahmedabad containing Oxyclozanide with levamisole) or Alzonic (A brand product of Intas, Ahmedabad comprising Niclosamide with Albendazole) depending on the parasitic infection. Yeast based micro mineral Bioplex high seven (A brand product of Alltech, Bangalore) boli, were procured. The shepherds were advised to dissolve 1o boli in one liter of drinking water over night and were requested to drench $10 \mathrm{ml}$ per anoestrus ewes on the second day after deworming, with help of $10 \mathrm{ml}$ disposable syringe, in both the seasons, as a solitary drench (Table 1). Eighty two thousand, three hundred and fifty ewes were supplemented, in two seasons, June- July and September-October, during 2015 to 2019. Each Bioplex High Seven bolus contains Zinc 360 $\mathrm{mg}$, Manganese $143 \mathrm{mg}$, Copper $60 \mathrm{mg}$, Iodine $4.5 \mathrm{mg}$, Cobalt $6.25 \mathrm{mg}$, Selenium $1.5 \mathrm{mg}$ and Chromium $1.68 \mathrm{mg}$.

\section{RESULTS AND DISCUSSION}

After medication, 93\% of the ewes were in estrus for 3 to 7 days irrespective of the presence or absence of stud rams and were bred duly. After completion of gestation, all the ewes were lambed within a week uniformly. There were no repeaters.

Prior to the breeding season all ewes were prone to oxidative stress due to nutrition, parasitic load, adverse climate like hot and cold, Stress due to parasitic load was removed with selected dewormers. The program was planned two weeks after the onset of monsoon. Owing to grazing, lush green pastures, the poor body condition sheep was improved and were fit for breeding. Supplementation of micro minerals would have replenished the mineral deficiencies, reduced the oxidative stress and primed the reproductive system and synchronized the estrus effectively. The outstanding results strongly support the fact that synchronization of estrus in sheep, unlike in cows, is more nutritional than physiological.
Minerals act as catalysts in both enzyme and hormone systems (Ceylan et al. 2008). Metalloenzymes, of which essential minerals are important constituents in the synthesis of many steroid minerals, hormones, (Yamaguchi et al. 2009; Yokus et al. 2010) and thyroid hormones Hess and Zimmermann, 2004; Gottsch et al. (2000) suggested the role of zinc in the reorganization of follicle, source of progesterone through the involvement of metalloproteinase-2 (MMP-2), member of zinc endopeptidase family.

Some evidence suggests that Manganese plays a role in the activity of certain endocrine organs. It is involved as a co-factor in cholesterol synthesis which is necessary for the synthesis of steroids like progesterone, estrogen and testosterone (Keen and Zidenburg-Cherr, 1990). Manganese supplementation has proven to be effective in shortening the postpartum anoestrus and increasing conception rates in dairy cows (Krolak, 1968). Chromium plays an important role in the secretion of pregnancy specific proteins from the uterine endometrium which is helpful in preventing early embryonic death. Chromium exerts a significant influence on follicular maturation and $\mathrm{LH}$ release. Signs of cobalt deficiency include delayed uterine involution, irregular estrous cycle and decreased conception rate (Satish Kumar, 2003). El Marsy and Nasr (1996) reported an increase in plasma progesterone and oestradiol-17 beta level after supplementation with Cobalt.

Improvement in conception rate at first service following selenium supplementation has been reported (McClure etal. 1986). The effect of iodine on secretion of thyrotropin-releasing factor, which in turn stimulates Prolactin secretion, can also have effect on length of estrus cycle (Khillare, 2007). Progesterone secretion was impaired due to a copper deficiency during the oestrus cycle and especially in late pregnancy in ewes (Van Niekerk, and Van Niekerk, 1989). Kandreze et al. (1997) reported negative correlation between plasma progesterone and zinc, during dry period in goats. Zinc deficiency results in alteration of steroidogenesis (Yamaguchi, et al. 2009). 
The induction of estrus with hormones is costly, laborious and requires technical assistance. In advertent injection of PG alpha to pregnant animals may induce abortion. Since insemination facility is not available and practicable, in the free range system, the only recourse is employing ram in hormonal induction of estrus. As a consequence more numbers of rams are required to cover all the ewes in the flock within 3 days of induction in hormonal induction. Non hormonal induction is simple, safe, effective and economical. The total cost of deworming and one dose of Bioplex will be $10+2$ in Indian rupees.

\section{CONCLUSION}

It is concluded that programmed synchronization of estrus and lambing is possible in Nellore ewes with yeast based micro-minerals, supplemented as Bioplex High seven, in fall and winter seasons with economy.

\section{ACKNOWLEDGEMENTS}

I acknowledge Dr V.N. Visvantha Reddy, Retired professor, Veterinary college Bangalore, Dr. K. Narayana Retired professor of Pharmacolgy, veterinary college, Bangalore, Dr. Paranjyothi Kani, Director, Bengalore Allergy Centre, Bangalore for their guidance and valuable suggestions.

\section{REFERENCES}

Agarwal, A., Gupta, S. and Sikka, S. 2006. The role of free radicals and antioxidants in reproduction. Current Opinion in Obstetrics and Gynecology, 18: 325-332.

Ali, A. 2007. Effect of time of eCG administration on follicular response and reproductive performance of FGA - treated Os-simi ewes. Small Rumin. Res., 72: 33-37.

Boscos, C.M. F.C. Samartzi F.C. Dellid S. Rogge, A. Stefanakis, A. and Krambovitis, A. 2002. Use of progestagen-gonadotrophin treatment in estrus synchronization of sheep. Theriogenology, 58: 1261-1272.
Brunner, M.A., Hanse, L.W. and Hogue, D.E. 1964. Use of 6-methyl-17-acetoxy progesterone and pregnant mare serum to induce and synchronize estrus in ewes. J. Anim. Sci., 23: 32-36.

Ceylan, A., Serin, I., Aksit, H. and Seyrek, K. 2008. Concentrations of some elements in dairy cows with reproductive disorders. The Bulletin of the Veterinary Institute in Pulawy, 52: 109-112.

Chan, S., Gerson, B. and Subramaniam, S. 1998. The role of copper, molybdenum, selenium, and zinc in nutrition and health. Clinics in Laboratory Medicine, 18: 673-685.

Clark, R.T. 1934. Studies of reproduction in sheep. 1. The ovulation rate of the ewe was affected by the plane of nutrition. Anat. Rec., 60: 125-134.

Doney, J.M., Gunn, R.G. and Griffiths, J.G. 1973. The effect of pre-mating stress on the onset of oestrus and the ovulation rate in Scottish Blackface ewes. J. Reprod. Fertil., 35: 381-384.

Dyrmundsson, O.R. and Lees, J.L. 1972. Effect of ramson the onset breeding activity in the clun forest ewe lamb. J. Agric. Sci. Camb., 79: 269-271.

El-Marsy, K.A. and Nasr, A.S. 1996. The role of folic acid and iron in reproductive performance of New Zealand white does and their kids. World Rabbit Science, 4: 127-131

Enhert, K. and Moberg, G.P. 1991. Disruption of estrous behavior in ewes by dexamethasone or management-related stress. J. Anim. Sci., 69: 2988-2994

Gordon, I. 1963a. The induction of pregnancy in the anoestrous ewe by hormonal therapy. II. Progesterone-pregnant mare's serum application in anoestrus. J. Agrie. Sci., Camb., 60: 43-66.

Gottsch, M.L., Murdoch, W.J. and Van Kirk, E.A. 2000. Tumour necrosis factor alpha upregulates matrix metalloproteinase- 2 activity in preovulatory ovine follicles metamorphic and endocrine implications. J. Reprod. Fert. Develop., 12: 75-80.

Hess S.Y. and Zimmermann M.B. 2004. The effect of micronutrient deficiencies on iodine nutrition and thyroid metabolism. Inter. J. Vit. Nutr. Res., 74: 103-115.

Kandreze, C.T., Lelewelyn, C.A. and Chivandi, E. 1997. Plasma progesterone, calcium, magnesium and zinc concentrations from oestrus synchronization to weaning in indigenous goats in Zimbabwe. Small Rumin. Res., 24: 21-26. 
Keen, C.L. and Zidenberg-Cheer, S. 1990. Manganese. Pp: 279-268. In present knowledge in nutrition. M.L. Brown Ed International Life science Institute Nutrition Foundation Washington, D.C.

Khanvilka, A.V. Shejal M.A., Rahane S.D. and Belhekar D.R. 2009. Breeding Practices in Sheep Farming, Vet. World, 2(1): 43-44.

Khillare, K.P. 2007. Trace Minerals and Reproduction in Animals. Intas. Polivet., 8(2): 308-314.

Kleemann, D.O. and Walker, S.K. 2005. Fertility in South Australian commercial Merino flocks: sources of reproductive wastage. Theriogenology, 63: 2075-2088,

Knights, M., Hoehn T., Lewis, P.E. and E.K. Ins keep. 2001. Effectiveness of intravaginal progesterone inserts and FSH for inducing synchronized estrus and increasing lambing rate in anestrous ewes. $J$. Anim. Sci., 79: 1120-1131.

Leyva, V., Bucknell, B.C. and Walton, J.S. 1998. Regulation of follicular activity and ovulation in ewes by exogenous pro-gestagen. Theriogenology, 50: 395-416.

Maurya, V.P., Sejian, V., Kumar, D. and Naqvi, S.M.K. 2010. Effect of induced body condition score differences on sexual behavior, scrotal measurements, semen attributes, and endocrine responses in Malpura rams under hot semi-arid environment. Journal of Animal physiology and Animal Nutrition, 94: 308-317.

McDowell, L.R.,Wilkinson, N., Madison, R. and Felix, T. 2007. Vitamins and minerals functioning as antioxidants with supplementation considerations. Florida Ruminant Nutrition Symposium. Best Western Gateway, Grand. Gainesville, FL, pp. 30-31.

McClure, T.J., Eamens, G.J. and Healy, P.J. 1986. Improved fertility in dairy cows after treatment with selenium pellets. Aus. Vet. J., 63: 144-146.

Monem, U.M.A. and El-Shahat, K.H. 2011. Effect of different dietary levels of inorganic zinc oxide on ovarian activities, reproductive performance of Egyptian Baladi ewes and growth of their lambs Bulgarian Journal of Veterinary Medicine, 14: 116123

Naqvi, S.M.K., Krishnappa Balaganur and Davendra Kumar. 2017. Advances in reproductive strategies to increase the production of small ruminants National Seminar on 'Small Ruminants: National Scope on Up scaling, Production to Products Value addition and their Safety, pp. 9-10.
Rhodes, L. and Nathaniels, P.W. 1988. Comparison of a con-trolled internal drug release device containing progesterone with intravaginal medroxyprogesterone sponges for estrus synchronization in ewes. Theriogenology, 30: 83183.

Satish Kumar. 2003. Management of infertility due to mineral deficiency in dairy animals". In proceedings of ICAR summer school on Advance diagnostic techniques and therapeutic approaches to metabolic and deficiency diseases.

Underwood, E.J. 1981. The mineral nutrition of livestock commonwealth agriculture bureaus. London.

Van Niekerk, F.E. and Van Niekerk, C.H. 1989. The influence of experimentally induced copper deficiency on the fertility of rams II. Macro and microscopic changes in the testes. J. South Afri. Vet. Assoc., 60: 28-31.

Verma D.N. 1999. Livestock Production and Management in Tropic. Kalyani Publishers.

Walkden-Brown, S.W., Martin, G.B. and Restall, B.J. 1999. Role of male-female interaction in regulating reproduction in sheep and goats. J. Reprod. Fert. Suppl., 54: 243-257.

Wheaton, J.E., Carlson, K.M., Windels, H.F. and Johnston, L.J. 1993. CIDR, new progesterone releasing intra-vaginal de-vice for induction of estrous and cycle control in sheep and goats. Anim. Reprod. Sci., 33: 127-141.

Wilde, D. 2006. Influence of macro and micro minerals in the periparturient period on fertility in dairy cattle. Animal Reproduction Science, 96: 240-249.

Yamaguchi, S., Miura, C., Kikuchi, K., Celino, F.T., Agusa, T., Tanabe, S. and Miura, T. 2009. Zinc an essential trace element for spermatogenesis. Proceedings of the National Academy of Sciences of the United States of America, 106: 10859-10864.

Yokus B., Cakir D., Icen, H., Durak, H. and Badem Kiran S. 2010. Prepartum and Postpartum Serum Mineral and Steroid Hormone Concentrations in Cows with Dystocia Veteriner Fakultesi Dergisi. 21(3): 185 - 190 .

Zarazaga, L.A., Guzman, J.L., Dominguez, C., Perez, M.C. and Prieto, R. 2004. Effect of plane of nutrition on seasonality of reproduction in Spanish Payoya goats. Animal Reproduction Science, 87: 253-267. 